\title{
Bite Force in Temporomandibular Dysfunction (TMD) and Healthy Complete Denture Wearers
}

\author{
Patrícia Tiemy Hirono HOTTA ${ }^{1}$ \\ Takami Hirono HOTTA ${ }^{2}$ \\ César BATAGLION ${ }^{1}$ \\ Rogério Fávaro PAVÃO ${ }^{1}$ \\ Selma SIÉSSERE ${ }^{1}$ \\ Simone Cecílio Hallak REGALO ${ }^{1}$ \\ ${ }^{1}$ Dental School of Ribeirão Preto, University of São Paulo, Ribeirão Preto, SP, Brazil \\ ${ }^{2}$ Dental School, University of Franca, Franca, SP, Brazil
}

\begin{abstract}
The signs and symptoms of temporomandibular dysfunction (TMD) may contribute to reduce bite force and muscular activity. The aims of this study were to compare bite force in complete denture wearers with TMD (TMD group) and without TMD (healthy group). The TMD group consisted of 9 individuals, who had worn a maxillary and a mandibular complete removable denture for more than 10 years. The healthy group consisted of 9 participants who wore dentures and had satisfactory interocclusal and maxillomandibular relationship. Helkimo Index was used to analyze the dysfunction level. Maximum bite force was measured using a digital dynamometer with capacity of $100 \mathrm{kgf}$ and adapted to oral conditions. The TMD group presented smaller mean bite force values than the healthy group, though without statistical significance $(\mathrm{p}>0.05)$. This outcome suggests that the TMD signs and symptoms and the structural conditions of the dentures did not affect the maximal bite force of complete denture wearers.
\end{abstract}

Key Words: complete denture, bite force, temporomandibular dysfunction.

\section{INTRODUCTION}

Temporomandibular dysfunction (TMD) is defined as a group of conditions characterized by pain or dysfunction in the temporomandibular joint (TMJ) and masticatory muscles (1), restrictive jaw movements and TMJ noises (2). TMD signs and symptoms may be more intensive in elderly patients and may also occur in complete denture wearers $(3,4)$, having a correlation with the patient's general health, head posture, chewing efficiency (3) and complete denture and occlusal conditions (5).

Mastication is a highly coordinated neuromuscular function involving jaw movements and continuous modulations of force $(6,7)$. It is considered one of most important functions of the masticatory system (8) and is directly involved in general body's health $(9,10)$.
When efficiently performed, mastication facilitates swallowing and nutrient absorption (11), which are especially important processes in elderly patients (12). The capacity to exert sufficient bite force is an indicator of normal masticatory function $(13,14)$.

However, the loss of teeth usually determines important changes in the masticatory system, which affect bone structures, oral mucosa and muscles (19). The use of inadequate complete dentures may also result in a decrease of muscular activity and reduce bite force in comparison to dentate subjects $(14,15)$. Several authors have demonstrated that patients diagnosed with TMD have lower maximum bite force values than healthy subjects (15-19).

The purpose of the present study was to compare bite force in complete denture wearers with and without TMD.

Correspondence: Profa. Dra. Simone Cecílio Hallak Regalo, Departamento de Morfologia, Estomatologia e Fisiologia, Faculdade de Odontologia de Ribeirão Preto, USP, Avenida do Café, S/N, 14040-904 Ribeirão Preto, SP, Brasil. Tel: +55-16-3602-4015. Fax: +55-163633-0999. e-mail: schregalo@forp.usp.br 


\section{MATERIAL AND METHODS}

\section{Subjects}

Eighteen edentulous individuals aged 63-80 years who met the inclusion and exclusion criteria were selected to participate in this study, being assigned to two groups: TMD patients (TMD group) and healthy subjects (healthy group).

The TMD group consisted of 9 female edentulous individuals, who had worn a maxillary and a mandibular complete denture for more than 10 years (Fig. 1). The inclusion criteria for this group were determined by a questionnaire based on Helkimo's index (26). The healthy group consisted of 9 edentulous females who presented dentures with satisfactory interocclusal and maxillomandibular relationship (Fig. 2). The subjects reported an adequate masticatory efficiency and were satisfied with their dentures. The oral mucosa was free of irritation and clinical signs of inflammation. None of the subjects of this group had history of mandibular dysfunction or any disease that could affect muscles of the masticatory system.

All participants were fully informed about the study purposes and experimental procedures and signed an informed consent form. The investigation was approved by the Research Ethics Committee of the Dental School of Ribeirão Preto, University of São Paulo (Process \#2006.1.1023.58.3).

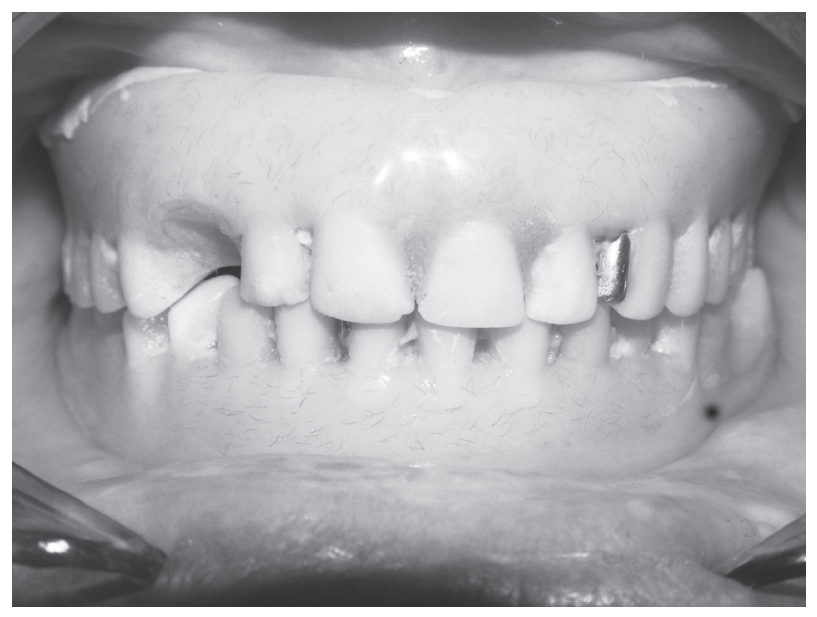

Figure 1. Intraoral anterior frontal view of a complete denture wearer with TMD.

\section{Bite Force}

Maximum bite force was measured using a digital dynamometer (model IDDK; Equipamentos Industriais Ltda., Taboão da Serra, SP, Brazil) with capacity of $100 \mathrm{kgf}$ and adapted to oral conditions. This equipment has a scale in kgf or $\mathrm{N}$ and a "set zero" button that permits an accurate control of the obtained values. This appliance uses electronic technology and comprises a bite fork, which consists of two metal rods with plastic covering. The bite fork is placed between the subject's teeth and held by the operator at the moment of maximum bite force reading. Its high-precision load cell and electronic circuit for indication of force provide accurate measurements that are easy to read from its digital three-liquid crystal screen. The study design has been previously described in detail (20).

All subjects received detailed full instructions and tested biting on the bite fork before actual recordings were made to assure reliability in the test procedure. Assessments were made in the right and left first molar region. Next, each subject was asked to bite on the device 3 times with maximum effort with a 2-min rest between trials. Bite force was recorded in kgf. Peak force measurements were displayed on the screen of a computerized interface and recorded for further analysis. The highest value among three measurements was considered the subject's maximum bite force.

The bite force data were subjected to statistical

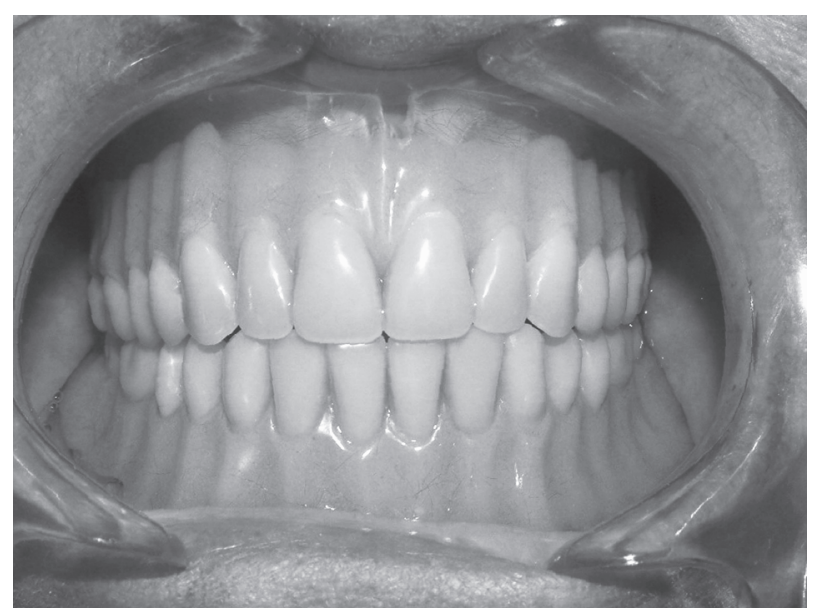

Figure 2. Intraoral anterior frontal view of a complete denture wearer without TMD. 
analysis using SPSS software for Windows (SPSS Inc., Chicago, IL, USA) and an independent t-test with a significance level of $5 \%$.

\section{RESULTS}

The mean maximum bite force value for the TMD group was $2.44 \pm 0.39 \mathrm{kgf}$ (right molar) and 2.72 $\pm 0.37 \mathrm{kgf}$ (left molar) and for the healthy group was $2.53 \pm 0.70 \mathrm{kgf}$ (right molar) and $3.32 \pm 0.76 \mathrm{kgf}$ (left molar). The independent t-test showed no statistically significant difference in maximum bite force values between the TMD and the healthy groups in either the right $(\mathrm{p}=0.919)$ or the left molar region $(\mathrm{p}=0.490)$.

\section{DISCUSSION}

In this study, a sample composed of complete denture wearers with and without TMD was selected with the aim of associating TMD presence with bite force magnitude. The evaluation of bilateral bite force in complete denture wearers is a very important analysis because it is involved in several critical stages of food breakdown. When bite force is inadequate, there is a reduction in the amount of ingested food, as well as a preference for soft foods, which can lead to an imbalance of nutritional phenomena in elderly patients (12).

It is well known that the maximum bite force and jaw muscle activity are reduced in complete denture wearers compared to dentate subjects $(1,4,14)$. The main reasons for this fact are most likely the advanced age and muscle atrophy, which makes muscles not to work as well as when natural teeth are present.

Alterations in the maxillomandibular relation (3), prolonged use of inadequate dentures, excessive wear of artificial teeth, parafunctional habits and ill-fitted denture bases due to alveolar ridge resorption (20) may also contribute to TMD development. The results are TMJ pain, jaw-closing muscle pain and fatigue, which are TMD signs and symptoms and may contribute to reduce bite force and muscular activity.

The discomfort of the dentures and the transducer may be more significant in the TMD group because of the patients' reluctance to undergo any more discomfort than they already had to experience (4).

The results of this study are in agreement with those of previous clinical trials (15-18) in which patients with TMD had lower maximum bite force values than healthy subjects. In the present investigation, the TMD group presented smaller mean bite force values than the healthy group, though without significance, as demonstrated by the statistical analysis. This result suggests that the TMD signs and symptoms and the structural conditions of the dentures did not affect the maximal bite force of complete denture wearers.

\section{RESUMO}

Os sinais e sintomas de DTM podem contribuir na redução da força de mordida e da atividade muscular. O objetivo deste trabalho foi comparar a força de mordida em indivíduos com prótese total com DTM (Grupo CDTM) e sem DTM (Grupo SDTM). O Grupo CDTM ( $\mathrm{n}=9$ ) era composto por indivíduos que utilizavam as mesmas próteses totais há mais de 10 anos. $\mathrm{O}$ Grupo SDTM $(n=9)$ por indivíduos com próteses totais satisfatórias quanto aos requisitos estruturais e funcionais, observados pelo profissional e relatados pelo paciente. O índice de Helkimo foi utilizado para análise do índice de disfunção. A força de mordida máxima foi medida na região de molares com gnatodinamômetro. Os resultados mostraram que o Grupo CDTM apresentou valor numérico médio de força de mordida menor que o Grupo SDTM, porém sem diferença estatisticamente significante entre os grupos avaliados $(p<0,05)$ sugerindo que os sinais e sintomas da DTM e as condições estruturais das próteses não afetaram os resultados da força de mordida.

\section{REFERENCES}

1. Al-Jabrah OA, Al-Shumailan YR. Prevalence of temporomandibular disorder signs in patients with complete versus partial dentures. Clin Oral Invest 2006;10:167-173.

2. Nomura K, Vitti M, Oliveira AS, Chaves TC, Semprini M, Siéssere S, et al.. Use of the Fonseca's questionnaire to assess the prevalence and severity of temporomandibular disorders in Brazilian dental undergraduates. Braz Dent J 2007;18:163167.

3. Zuccolotto MCC, Vitti M, Nóbilo KA, Regalo SCH, Siéssere $\mathrm{S}$, Bataglion C. Electromyographic evaluation of masseter and anterior temporalis muscles in rest position of edentulous patients with temporomandibular disorders, before and after using complete dentures with sliding plates. Gerodontology 2007;24:105-110.

4. Tortopidis D, Lyons DMF, Baxendale RH. Bite force, endurance and masseter muscle fatigue in healthy edentulous subjects and those with TMD. J Oral Rehabil 1999;26:321-328.

5. Dervis E. Changes in temporomandibular disorders after treatment with new complete dentures. J Oral Rehabil 2004;31:320-326.

6. Karkazis HC, Kossioni AE. Surface EMG activity of the masseter muscle in denture wearers during chewing of hard and soft food. J Oral Rehabil 1998;25:8-14.

7. Piancino MG, Farina D, Talpone F, Castroflorio T, Gassino G, Margarino V, et al.. Surface EMG of jaw-elevator muscles and chewing pattern in complete denture wearers. J Oral Rehabil 2005;32:863-870.

8. Henrikson T, Ekberg E, Nilner M. Masticatory efficiency 
and ability in relation to occlusion and mandibular dysfunction in girls. Int J Prosthodont 1998;11:125-132.

9. Wostmann B, Michel K, Brinkert B, Melchheier-Weskott A, Rehmann P, Balkenhol M. Influence of denture improvement on the nutritional status and quality of life of geriatric patients. J Dent 2008;36:816-821.

10. Miura $\mathrm{H}$, Araki $\mathrm{Y}$, Hirai $\mathrm{T}$, Isogai $\mathrm{E}$, Hirose $\mathrm{K}$, Umenai $\mathrm{T}$. Evaluation of chewing activity in the elderly person. J Oral Rehabil 1998;25:190-193.

11. Kapur KK, Okubo J. The effect of impaired mastication on the health of rats. J Dent Res 1970;49:61-68.

12. Galo R, Vitti M, Santos CM, Hallak JEC, Regalo SCH. The effect of age on the function of the masticatory system - an electromyographical analysis. Gerodontology 2006;23:177182.

13. Bates JF, Stafford GD, Harrison A. Masticatory function - a review of the literature. Part II and III. J Oral Rehabil $1975 ; 2: 57-67$.

14. Carlsson GE. Bite force and chewing efficiency. In: Kawamura Y, ed. Frontiers of Oral Physiology. vol. 1. Basel: Karger; 1974:265-276.

15. Shi CS. Proportionality of mean voltage of masseter muscle to maximum bite force applied for diagnosing temporoman- dibular joint disturbance syndrome. J Prosthet Dent 1989;62:682-684.

16. Kroon GW, Naeije M. Electromyographic evidence of local muscle fatigue in a subgroup of patients with myogenous craniomandibular disorders. Arch Oral Biol 1992;37:215-218.

17. Liu ZJ, Yamagata K, Kasahara Y, Ito G. Electromyographic examination of jaw muscles in relation to symptoms and occlusion of patients with temporomandibular joint disorders. J Oral Rehabil 1999;26:33-47.

18. Wahlund K. Temporomandibular disorders in adolescents. Epidemiological and methodological studies and a randomized controlled trial. Swed Dent J Suppl 2003;164:inside front cover, 2-64

19. Kogawa EM, Calderon PS, Lauris JRP, Araujo CRP, Conti PCR. Evaluation of maximal bite force in temporomandibular disorders patients. J Oral Rehabil 2006;33:559-565.

20. Santos JFF, Marchini L, Campos MS, Damião CF, Cunha VPP, Barbosa CMR. Symptoms of craniomandibular disorders in elderly Brazilian wearers of complete dentures. Gerodontology 2004;21:51-52.

Accepted August 28, 2008 